\title{
Formative Research on Telidon and Educatio
}

By Avi Soudack

Bob Karam

ABSTRACT

TVOntario recently conducted a field mative research study based on the trial
has beel volved the deployment of Telidon terminals at public schools, colleges, unive-
sities, libraries, and special-educationa institutions. The fornative research effort Telidon that could be applied to the development of Telidon in education. The research involved a variety of complementary research methoding observation, interviews, an survey questionnaires. During the field
trial, users tended to explore Telidon rather than use it as a learning tool.
Several factors were identified as influen cing how Telidon was implemented a the contact person, and a need for printe documentation. The database was foun to contain too few sequences of interes and the search for sequences or informa-
tion was considered too time consuming. The graphic design and educational leve
of sequences were found to offer problems. Formative research provided systematic information of this type on

TVOntario has recently completed a system, Telidon, in which education videotex applications were explored. The field trial included a major formative research effort to gather information that
could be applied to the future developcould be applied to the future develop
ment of Telidon and other computercommunication

Supported by the Department of Communications, the field trial involved the implementation of Telidon videotex and tions across Ontario (Syrett, 1981; Bowers installed at elementary and secondary schools, colleges and universities, public libraries, and special-educational institutions. The Telidon project team engaged
TVOntario's Office of Project Research to undertake a formative evaluation Telidon in education by examining the Avi Soudack and Bob Karam are research officers at
research, TVOntario has recently been completed and reported
(Office of Project Research, TVOntario, Office.

The research team was not involved in the actual running of the field trial Distribution of equipment and materials,
and liaison with the participating educational institutions, were the formidable task of the Telidon project team. The with the project team, benefiting from
withearchers, however worked considerable assistance in the admintramployed.

At most sites one person became the
major contact between TVOntario's Telidon project team and the institution. Most often, this person created a Telido sequence (a series of Telidon pages) for
inclusion in the TVO database. Throughout the field trial the contact peo ple administered the use of the terminal at their institutions, often with the

The Office of Project Research set up rearch team whose primary task was to of Telidon in education to TVOntario Telidon project team and all those involv-
ed in the field trial. Since the field trial was exploratory and the research purely be as unobstrusive as possible, trying no to intervene in the spontaneous ex-
perimentation undertaken by the field perimentation

The introduction of so new and un-
Theicints. precedented a technology as Telidon into the educational system raise many que thypotheses. At the outset, the research team, in consultation with the project
team, specified a number of categories team, specified a number of categories
from which research questions should emerge and information could be included: 1. Patterns of use: With so many pro-
mises and ideas in the air, the first priorty of research was a basic record of how
Telidon was used during the field trial. 2. Implementation: The manner in The Telidon Field Trial and formative * The Telidon Field Trial and formative
research effort were supported by the Federal ss would like to thank Pat P sons, Hélène Pedneault, and Kay Duggan for their contributions to the research, and
acknowledge the assistance of John Syrett acknowledge the assistance of John Syrett
director of the Telidon Field Trial, TVOntario and Olga Kuplowska, manager of the Office of
Project Research, TVOntario. The opinions exProject Research, TVOntario. The opinions ex-
pressed in this paper are solely those of the
authors. the participating institutions was of con-
siderable interest. The research examined the way teachers, students, and librarians
adapted Telidon to their own purposes and the degree to which Telidon use was

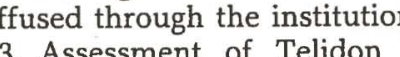
3. Assessment of Telidon sequences
and database: The content of the Telido educational database produced during the field trial was examined in an attempt gather information on how best to desig purposes. The most important aspect of educa
tional materials - their learning impact - was the most elusive to research. However, some preliminary research was

4. Perceptions: Future development of have to take account of users' to the technology. So administrators teachers, librarians, and students were given opportunities to express the

METHODS

The research team collected data from 34 sites. These sites included primary secondary, and postsecondary schools as
well as public libraries and special educational institutions.

The research effort included a number of complementary research methods
structured telephone interviews with the contact person at each site; observatio conducted during on-site visits, person interviews wiln olaff at the participati to approximately 400 secondary and
postsecondary school students who used Telidon in their classes; questionnaires for 200 teachers and administrators at the participating institutions; and a controlli
study, carri $=d$ out to examine the learnin impact of a Telidon CAI sequence.

\section{FINDINGS}

The breadth of the research effort provided a great deal of data under each of
the research categories. The following are

selected main findings that refle
general direction of the results.

1 Patterns of Use

1.1 Learning about Telidon

Thelidon consisted of learning "ajor us the technology, rather than "with" or demonstrations or classes about "the new technologies." Telidon itself was ofte the object of interest.

It became clear during the field trial

VOLUME 13 , NUMBER 3, 198 ta unified definition of Telidon or its
de of application was not possible. On pode of application was not possible. On als of the participating institutions dhe patterns of use.

Do levels - the institutional and the wo levels - the institutional and the
epartmental. At the institutional level, or instance, universities were primarily interested in extensive research on the
echnology and its social impact. On the echnology and its social impact. On the oking for new forms of teaching atives to stimulate and motivate their tudents. These different needs placed ifferent demands on the databases At the during the field tria.

stitution the use of Telido within each ined by the physical location of the elidon terminal, and the discipline or unction of the department that ad-
ministered the terminal. For example, at he secondary-school level, terminals were sometimes located in classroom or the different departments looked for different types of sequences:
mathematics teachers were often innathematics teachers were often in-
erested in computer-assisted lessons; seography teachers sought sequences that
could be used in class as visual aids. The epartmental specialization also limited he use of the system by staff and tudents

1.3 System Players

to use Telidon at their leisure allowroups of students were drawn to "play he system." These students searched for
game sequences on the database lof game sequences on the database lof
which there were few). However, they lso enjoyed the exploration of the
latabase as a game in itself. We called heir exploration "system playing"
lecause it was not motivated by any parcular information search: rather, they atabase was organized, without regard contents.

Implementation

2.1 Role of Contact Person a

There was limited spontaneous diffu-

on during the period of the field trial. At

nany sites few teachers, staff, or students

other than the contact person used the
system. The contact person emerged as

system. The contact person emerged as
the key link in the process of diffusion of Telidon into his or her educational institu-
Peling ion. The administrative position of the ontact person could influence the use of elidon within a site. For instance, usually more effective in disseminating information about Telidon than motivation, and academic discipline of he contact persons affected their promo作 2.2 Printed Documentation There was a demand, at the elementary and secondary schools, for printed sup documentation on basic technical issues, and on pedagogical matters as well. They wanted suggestions on what Telido material to use and how to use it. This demand came especially from those who had not produced sequences or had not eachers suggested that the desire for printed material may have been part of arger need for guidance on how to apply elidon to teaching.

3 Assessment of Telidon Sequence nd Databases

Participants in the field trial could accencational database of Tidon "pages" or videoscreens of ima and text. The pages of sequence are all structure. For instance, a sequence may be a quiz on world history composed of 50 pages - some presenting questions,
thers providing answers. The sequences in the database varied considerably in form and content - from games to struc information

The creation of a 60 -sequence database was a major effort, involving considerable various sites produced sequences at puters designed for page and sequence creation. The Telidon project team in cluded sequence creators who produced
their own sequences and trained and assisted the volunteers.

Despite this effort, Telidon users con sidered the field trial database too small. In a survey conducted at the end of the lack of sequences of appropriate subject impediment to Telidon use. While 60 se quences represent a considerable achievement, they were spread over 45 of study and educational levels within

3.2 Graphics and Educational Design pressive - users of all ages and educa-

ional backgrounds were impressed with found to be a subtle and at times difficult design problem. In the opening pages of a setimulant, whetting the appetite. of the sequence were also very successful - for instance, maps in a sequence on geology. However, it was found that if a throughout a sequence, it can be frustrating to the user.

3.3 Information Searches with a MenuDriven Branching Structure with a variety of types of computers ved with assessing system required the user to make a series of selections from indexes displayed on the screen. The indexes fore arranged hierarchically - moving first searched for the sequence of interest at the most general level - for instance, "government services." The user would then move to the next index, choosing among history, science, or literature seand retriend the sequences of interest by consulting a series of indexes, or as they are called in computer parlance, "menu

pages."
Librarians and experienced computer users found the menu-driven user searfor one page of information many preceding "menu" pages had to be examined. Other users recommended that cross-references and quences easier and quicker. The database so this problem of accessing on-line information would be compounded in growing

3.4 Computer-Assisted Instruction
databases. Several computer-assisted instruction ario database. In these sequences sudents learned material presented on tons on the content materials as they pro-
tion he sequence. instruction instruction applications other computer systems found the Telidon sequences limited in comparison. during the field trial had no form of 列 
New Software Evaluation Instrument The National Science Teachers Association (NSTA) has published a new strument. Prepared by the NSTA Task Force on Assessing Computer-Augmented Science Instructional Materials the new instrument is designed to be used primarily in school-level or district-leve evaluations of science instructional software packages.

the January 1984 issues of NSTA's perodicals, The Science Teacher, Science and Children and the Journal of College Science Teaching. Copies may also be ob-
tained from NSTA, 1742 Connecticut tained from NSTA, 1742 Connecticut

Avenue NW, Washington, DC 20009.
For more information, contact Leopold

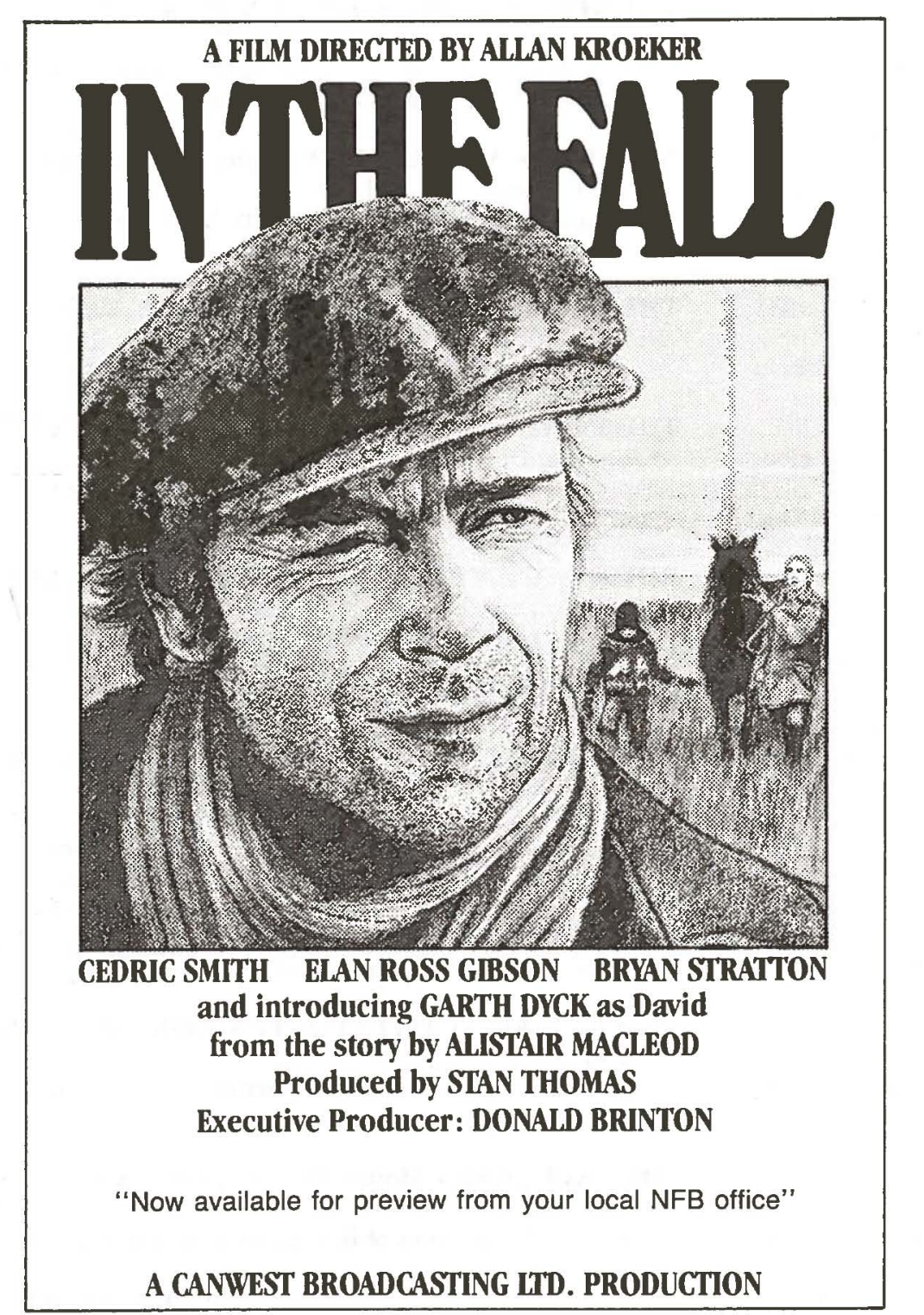

A CANWEST BROADCASTING ITD. PRODUCTION $412 / 624-4821$ ary Offered by Searchmart thousands of individual applications systems software packages online.
E. Klopfer, Prof. of Educ., Chair, NSTA
Task Force, Univ. of Pittsburgh, LRDC Bldg., 3939 O'Hara St., Pittsburgh, PA

Free Access to On-Line Softwar

Searchmart Corp., a South Florida firm information retrieval systems, is offering a Free Access Software Library that lists describes and demonstrates tens oftware will be updated daily and categorized by manufacturer, publisher or vendor, operating systems compatibility, protocol requirements, program inforition, price and ordering The unique feature is the free on-line CORMATIVE RESEARCH Continued from page 11

mance statistics were not compiled. Fur-
ther, the system did not allow the dire entry of text or numeric responses to a question posed in a sequence: the user
could only enter page numbers through a numeric key pad. Of course, these problems are not endemic to Telidon, whose graphic system can be adapted to dif-
ferent host computing facilities ferent host computing facilities and technical configurations. However, they
alert the developers of Telidon systems to the need to ensure that any computerassisted instruction sequences are sufficiently flexible in design and powerful in computing ability to compete with oth available systems.
3.5 Learning $I m$

3.5 Learning Impact

A preliminary evaluation of on suggested that certain Telidon sequences may be effective for some students and ineffective for others. In this study mor advanced students learned as well fro
Telidon as from a traditional teach presentation. However, students Telidon tended to score less well on lear ing tests than students taught by small portion of the grade 9 mathematic
curriculum and allowed students to $g$ curriculum and allowed students to $g$
through the material without teache assistance. Though this study could no employ complete controls on all relate variables, these findings indicate that educational sequences must be designed with careful consideration of
with whom they will be used.

3.6 Designin sequences

3.6 Designing Sequences

possible differential impact of seques

VOLUME 13, NUMBER 3, 19
LOVE'S LABOUR'S LOST

companions come out to meet the ladies negotiations are firm, but towards the end it is obvious that the king is quite taken by Act III. Don Armando is in love

with the dairy maid. He asks his page to and Don Armando discusses love, and the dairymaid's probable virtue. Finally Don Armando, desperately in love, determines to release Costard from his custody, so
that Costard will deliver a message to his love.

Enter Biron. He too, apparently is in love, (Isn't everybody? and he gives
Costard another letter, destined for
Rosaline. Thus Shakespeare contrasts the Rosaline. Thus Shakespeare contrasts the
physical passion on the one hand, with physical passion on the one hand, with
true, honest love, on the other. And Costard now has two letters to deliver. Act IV. There are three scenes in this act. The princess and her ladies are going shooting in the forest, when they are in ter meant for Costard carrying the love letthat the letter be rine. The princess asks pomposity. And, it is, of course, the wrong letter.

The second scene introduces two new characters, the school teacher and the Since she is illiterate, she asks the letter. to read it for her, which he does, and which the school teacher is able to promptly criticise. Again it is the wrong letter, which the characters note, and so they send Jaquenetta to the king!

Scene three. Biron is rediculed by the King, Longaville, and Dumain who see
that Biron is the first to break his a quick philosophic flourish, Biron explains that the only real books are the
eyes of the ladies! argument is eyes of the ladies! argument is en-
thusiasticlly accepted, and the four deterthusiasticlly accepted, and the four deter-
mine to go off and study what should be
studied!

GO PROGRAM

D. Final report of the Brookline logo project: profiles of individual
student work. Logo Memo 54, MIT Logo Group, 1979. unust 1982, 8 (7), 116-134.

D., \& Weir, S. Logo: a computer en-
vironment for learning disabled students. The Computing disabled (8) May 1981.
S. The evaluation and cultivaion of spatial and linguistic cerebral palsy (Memo No. 470). MIT
(Mendiduals with AI Labortaory, Cambridge, October 1979 .

"For women's eyes this doctrine

They are the books, the arts, the That show, contain, and nourish all the world.'

Act V. More fun is made of jargon and the constable schoolmaster, the curate each other full tilt. Moth epitomizes the jargonistic humor in which all indulge, saying that "They have been at a grea feast of languages, and stolen the scraps." the longest word of them all probably the longest word of them all, probably
good enough to enter the Guiness Book of follows, but some essential papers have and her ladies must stay the night. Th

Records ... Honorificabilitudinitatibus.
The final scene returns princess and her ladies. All us to th gifts from their admirers. Upon hearin make an that the men are about Muscovite costume, the ladies determin to disguise themselves. Indeed, the humorous Pagent of the Nine Worthies follows as entertainment. Suddenly the accused of getting as Don Armando is And more bad news arrives. The King of France is dead. The princess resolves to return home immediately. The men all decide to make intentions but the ladies year before they will marry them. Even De will spend three to prove himself . end, love has been proclaimed, but, at least a year must pass before any marriages will take place. Indeed, for the moWe teast, love's labour had been lost. the art/scien discussion with a look at ing up in educational technology of the 1980 's. We have concluded with

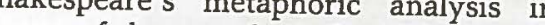
terms of love and study. Who wins? Perhaps we should be the ambiguous, tional technology is mo thane. Educait is a state of mind. And educational technologists will appreciate that in
Love's Labour's Lost, the master playwrite is ... just possibly ... speaking ***

We began our discussion with a look at he art/science dichotomy so often cropping up in educational technology of the
$1980^{\prime}$ s. We have concluded with Sheakespeare's metaphoric analysis in terms of love and study. Who wins?
toris Sheakespeare is predictably ambiguous. 作 it is a state of mind. And educational technologist will appreciate that in Love's just possibly .... speaking to uste is ...

\section{MEDIA NEWS}

page 9

Multimedia for Manitoba?

An association for multi-image in Manitoba is in the process of being other provinces belonging to similar associations with ideas which might help the fledgeling organization, are invited to contact Cliff Kehler, c/o Inland AV, 1645
St. James St., Winnipeg 